\title{
Vitamin D deficiency is associated with increased risk of Alzheimer's disease and dementia: evidence from meta-analysis
}

\author{
Liang Shen and Hong-Fang Ji*
}

\begin{abstract}
Background: In recent years, the associations between vitamin D status and Alzheimer's disease (AD) and dementia have gained increasing interests. The present meta-analysis was designed to estimate the association between vitamin $D$ deficiency and risk of developing $A D$ and dementia.

Methods: A literature search conducted until February 2015 identified 10 study populations, which were included in the meta-analysis. Pooled risk ratios (RRs) and $95 \%$ confidence interval (Cl) were calculated with a random-effect model using Stata software package.

Results: Results of our meta-analysis showed that subjects with deficient vitamin D status $(25(\mathrm{OH}) \mathrm{D}$ level $<50 \mathrm{nmol} / \mathrm{L})$ were at increased risk of developing AD by $21 \%$ compared with those possessing $25(\mathrm{OH}) \mathrm{D}$ level $>50 \mathrm{nmol} / \mathrm{L}$. Similar analysis also found a significantly increased dementia risk in vitamin $D$ deficient subjects. There is no evidence for significant heterogeneity among the included studies.

Conclusion: Available data indicates that lower vitamin D status may be associated with increased risk of developing $A D$ and dementia. More studies are needed to further confirm the associations and to evaluate the beneficial effects of vitamin $\mathrm{D}$ supplementation in preventing $\mathrm{AD}$ and dementia.
\end{abstract}

\section{Introduction}

Alzheimer's disease (AD) is the most common form of dementia in the elderly. With the accelerating population aging process, the prevalence of $\mathrm{AD}$ and dementia is estimated to rise steadily [1,2]. Despite considerable effort has been devoted to the drug discovery for $A D$, there is no effective agent to combat it at present. Thus, it is urgent to identify specific modifiable risk factors for these disorders.

In recent years, the associations between vitamin $\mathrm{D}$ and $\mathrm{AD}$ or dementia have attracted growing interests [3-5]. First, accumulating studies indicate that vitamin $\mathrm{D}$ deficiency is prevalent in $\mathrm{AD}$ and dementia patients $[6,7]$ and a meta-analysis study supported that AD patients possess lower level of 25-hydroxyvitamin D $[25(\mathrm{OH}) \mathrm{D}]$ compared with age-matched healthy controls [8]. Second, low 25(OH)D level may be a potential

\footnotetext{
*Correspondence: jhf@sdut.edu.cn

Shandong Provincial Research Center for Bioinformatic Engineering and Technique, School of Life Sciences, Shandong University of Technology, Zibo 255049, P. R. China
}

risk factor of developing $\mathrm{AD}$ and dementia as supported by recent studies $[9,10]$. However, there is a lack of a comprehensive evaluation on whether vitamin $\mathrm{D}$ deficiency correlates with high risk of $\mathrm{AD}$ and dementia development, which has important implications for the prevention of these disorders. Therefore, the present study was designed to estimate the association between vitamin $\mathrm{D}$ deficiency and risk of developing $\mathrm{AD}$ and dementia.

\section{Methods}

Search strategy and study selection

The meta-analysis was performed according to the PRISMA guidelines. With the keywords "Alzheimer's disease" or "dementia" and "vitamin D" or " $25(\mathrm{OH}) \mathrm{D}$ ", the literature search was conducted in the MEDLINE database from inception until February 2015. The references lists of retrieved articles were also manually reviewed to identify relevant studies missed by the search strategy. The potentially relevant references were identified for inclusion by reviewing titles and/or abstracts, and/or full 
text of all citations identified with database searches. Vitamin D deficiency was defined as a serum $25(\mathrm{OH}) \mathrm{D}$, a stable marker of vitamin $\mathrm{D}$ status, concentration of $\leq$ $50 \mathrm{nmol} / \mathrm{L}$, which has been widely used in relative studies as the cut-off point for vitamin D deficiency [11]. For consistency, serum concentrations of $25(\mathrm{OH}) \mathrm{D}$ present in $\mathrm{nmol} / \mathrm{L}$ were converted to $\mathrm{ng} / \mathrm{mL}$ by using the conversion factor $(1 \mathrm{ng} / \mathrm{mL}=2.5 \mathrm{nmol} / \mathrm{L})$.

The eligible studies must meet the following inclusion criteria: i) original studies to evaluate the association of vitamin $\mathrm{D}$ status and risk of developing $\mathrm{AD}$ or dementia; ii) providing the odds ratios (ORs), relative risks (RRs) or hazard ratios (HRs) with $95 \%$ confidence intervals (CI) of developing $\mathrm{AD}$ or dementia in vitamin $\mathrm{D}$ deficient subjects comparing with subjects with serum $25(\mathrm{OH}) \mathrm{D}$ concentration of $>50 \mathrm{nmol} / \mathrm{L}$. The animal experiment, review and mechanistic research studies were excluded. Duplicate articles were excluded in the study. Only references published in English is considered.

\section{Data extraction and analysis}

The collected information from each identified study include: the first author, year of publication, country, average age, OR, and $95 \% \mathrm{CI}$, and adjusted factors. Two reviewers extracted the data from each study independently and finally verified the extracted data. The metaanalysis was performed using the Stata statistical software package, version 12.0 (StataCorp, College Station, Texas, USA). The random effect model was employed during all the analyses. The heterogeneity was assessed through the $I^{2}$ statistic.

\section{Results}

\section{Study characteristics}

The study selection flowchart was detailed in Fig. 1. Overall, 526 potentially relevant references were initially identified through database search and 298 were obtained for further screen after duplicates removed. Following initial titles and/or abstracts screening 226 references were excluded. After full text assessment of the remained articles five studies, which include 10 study populations, were identified and included in the present analysis [9, 10, 12-14]. For the five eligible studies, two studies are prospective cohort and three are cross-sectional studies. Five eligible studies were conducted in Denmark, USA, UK, France and Germany, respectively. All included studies were published in English. The years of publication ranged from 2010 to 2015.

\section{Vitamin D deficiency and risk of $A D$}

Five study populations from three studies were included in the meta-analysis of the association between vitamin $\mathrm{D}$ deficiency and risk of developing $\mathrm{AD}[9,10,12]$. Main characteristics of the included studies were provided in

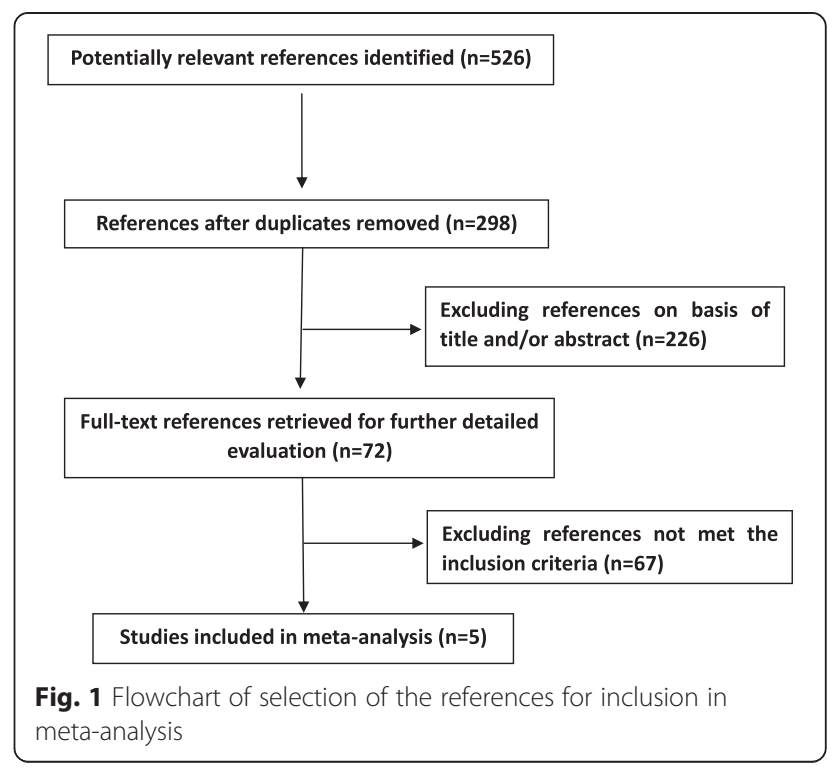

Table 1. Forest plot of the included studies investigating risk of $A D$ in vitamin $D$ deficient subjects was shown in Fig. 2. Results of the prospective cohort studies showed that vitamin $\mathrm{D}$ deficiency was associated with increased risk of $\mathrm{AD}$ occurrence compared to the subjects with $25(\mathrm{OH}) \mathrm{D}$ level $>50 \mathrm{nmol} / \mathrm{L}$, overall $\mathrm{OR}=1.21,95 \% \mathrm{CI}$ 1.01-1.40. The $I^{2}$ value was $0.0 \%$, which suggested that there was no evidence for significant heterogeneity. The inclusion of one cross-sectional study negligibly affected the results (Fig. 2).

\section{Vitamin D deficiency and risk of dementia}

Table 2 provided the summary of the included studies concerning vitamin $\mathrm{D}$ deficiency and risk of developing dementia [9, 12-14]. Meta-analysis of the prospective cohort studies showed that the risk of developing dementia was increased by $63 \%$ in comparison with the subjects with $25(\mathrm{OH}) \mathrm{D}$ level $>50 \mathrm{nmol} / \mathrm{L}$ according to the estimated $\mathrm{OR}=1.63,95 \%$ CI 1.09-2.16 (Fig. 3). Similar results were observed from meta-analysis restricted to prospective cohort studies $(\mathrm{OR}=1.48,95 \%$ CI $0.63-2.33)$ and the $I^{2}$ value suggested that there was no evidence for significant heterogeneity among the studies (Fig. 3).

\section{Discussion}

As a fat-soluble steroid hormone, vitamin D possesses a wide range of health-promoting effects and has potential therapeutic benefits in combating many disorders, including the non-skeletal, age-associated disorders [15-17]. In recent years, the associations between vitamin $\mathrm{D}$ and $\mathrm{AD}$ or dementia have attracted increasing attentions $[3-5,18-21]$. The meta-analysis by Etgen et al. found that participants with low vitamin D status showed an increased risk of cognitive impairment compared with 
Table 1 Summary characteristics of studies included in the analysis of vitamin D deficiency and risk of AD

\begin{tabular}{|c|c|c|c|c|c|c|c|c|c|}
\hline References & Year & Country & Study type & Participants & $\begin{array}{l}\text { Average age } \\
\text { (years) }\end{array}$ & OR & $95 \% \mathrm{Cl}$ & $\begin{array}{l}\text { 25(OH)D } \\
\text { (nmol/L) }\end{array}$ & Adjustment \\
\hline Afzal [10] & 2014 & Denmark & $\begin{array}{l}\text { Prospective } \\
\text { cohort }\end{array}$ & 2384 & - & 1.25 & $0.95-1.64$ & $<25$ & $\begin{array}{l}\text { Age, sex, month of blood sample, smoking } \\
\text { status, body mass index, leisure time and } \\
\text { work-related physical activity, alcohol } \\
\text { consumption, income level, education, } \\
\text { baseline diabetes mellitus, hypertension, } \\
\text { cholesterol, high-density lipoprotein } \\
\text { cholesterol, and creatinine }\end{array}$ \\
\hline Afzal [10] & 2014 & Denmark & $\begin{array}{l}\text { Prospective } \\
\text { cohort }\end{array}$ & 4087 & - & 1.12 & $0.90-1.4$ & $25-50$ & $\begin{array}{l}\text { Age, sex, month of blood sample, smoking } \\
\text { status, body mass index, leisure time and } \\
\text { work-related physical activity, alcohol } \\
\text { consumption, income level, education, } \\
\text { baseline diabetes mellitus, hypertension, } \\
\text { cholesterol, high-density lipoprotein } \\
\text { cholesterol, and creatinine }\end{array}$ \\
\hline Littlejohns [9] & 2014 & UK & $\begin{array}{l}\text { Prospective } \\
\text { cohort }\end{array}$ & 1615 & $73.6 \pm 4.5$ & 2.22 & $1.02-4.83$ & $<25$ & $\begin{array}{l}\text { Age, season of vitamin D collection, } \\
\text { education, sex, BMl, smoking, alcohol } \\
\text { consumption, and depressive symptoms }\end{array}$ \\
\hline Littlejohns [9] & 2014 & UK & $\begin{array}{l}\text { Prospective } \\
\text { cohort }\end{array}$ & 1615 & $73.6 \pm 4.5$ & 1.69 & $1.06-2.69$ & $25-50$ & $\begin{array}{l}\text { Age, season of vitamin D collection, } \\
\text { education, sex, BMI, smoking, alcohol } \\
\text { consumption, and depressive symptoms }\end{array}$ \\
\hline Buell [12] & 2010 & USA & Cross-sectional & 318 & $73.5 \pm 8.1$ & 2.65 & $0.99-7.16$ & $\leq 50$ & $\begin{array}{l}\text { Age, race, sex, body mass index, and } \\
\text { education, kidney function, multivitamin } \\
\text { use, season, diabetes, hypertension, } \\
\text { plasma homocysteine, and ApoE allele } \\
\text { status }\end{array}$ \\
\hline
\end{tabular}

normal vitamin D status [22]. Similarly, Balion et al. found that $\mathrm{AD}$ patients had a lower vitamin $\mathrm{D}$ concentration compared with controls and participants with higher vitamin D concentrations had a higher average MiniMental State Examination score through meta-analyses
[23]. The present study was designed to further explore whether low vitamin D status predicts increased incidence of $\mathrm{AD}$ and dementia. The data showed that subjects with deficient vitamin D (serum $25(\mathrm{OH}) \mathrm{D}$ level $\leq 50 \mathrm{nmol} / \mathrm{L})$ were at higher risk for the development of $\mathrm{AD}$ and

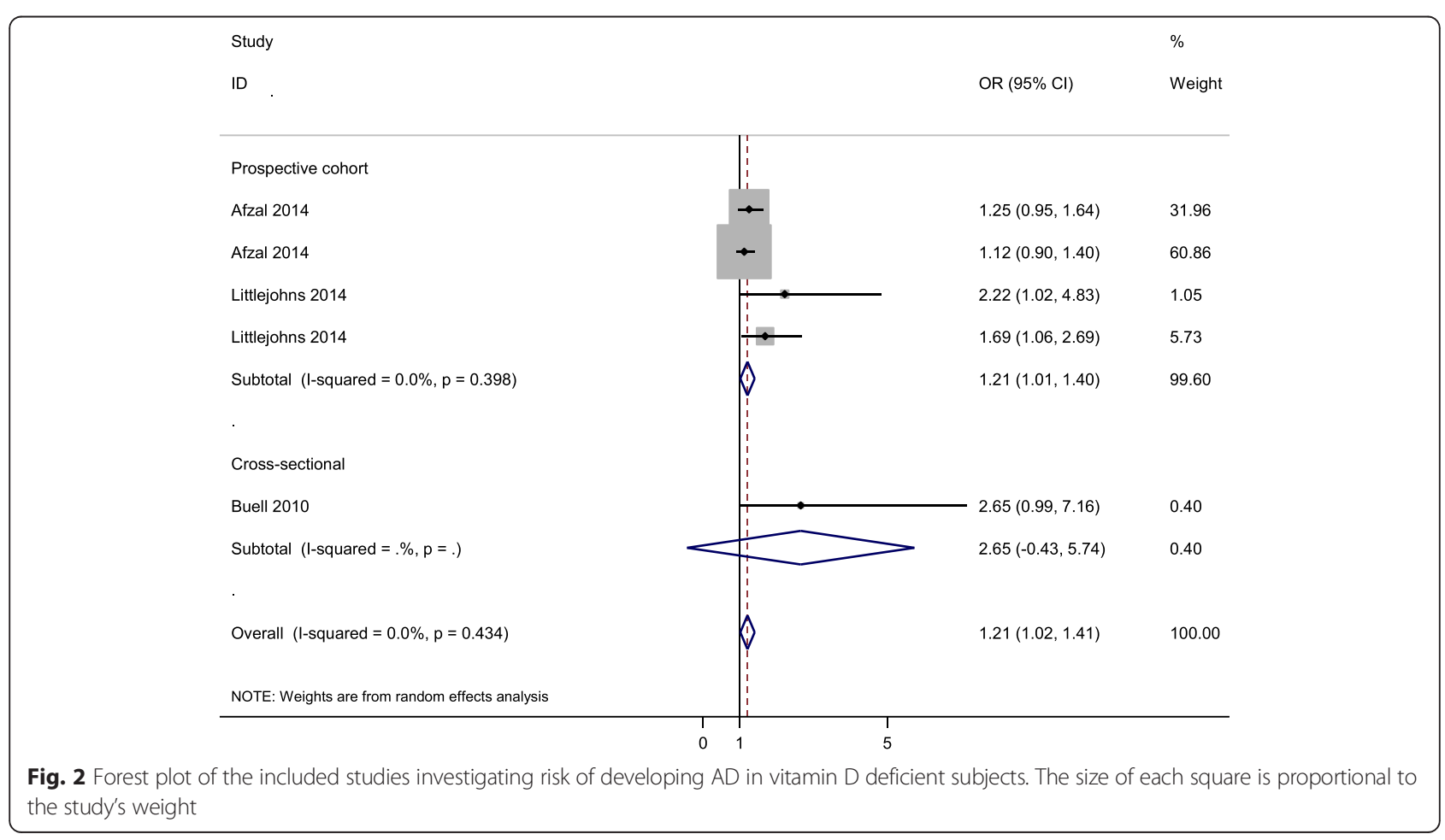


Table 2 Summary characteristics of studies included in the analysis of vitamin D deficiency and risk of dementia

\begin{tabular}{|c|c|c|c|c|c|c|c|c|c|}
\hline References & Year & Country & Study type & Participants & $\begin{array}{l}\text { Average age } \\
\text { (years) }\end{array}$ & OR & $95 \% \mathrm{Cl}$ & $\begin{array}{l}25(\mathrm{OH}) \mathrm{D} \\
(\mathrm{nmol} / \mathrm{L})\end{array}$ & Adjustment \\
\hline Littlejohns [9] & 2014 & UK & $\begin{array}{l}\text { Prospective } \\
\text { cohort }\end{array}$ & 1547 & $73.6 \pm 4.5$ & 2.25 & $1.23-4.13$ & $<25$ & $\begin{array}{l}\text { Age, season of vitamin D collection, } \\
\text { education, sex, BMl, smoking, alcohol } \\
\text { consumption, and depressive symptoms }\end{array}$ \\
\hline Littlejohns [9] & 2014 & UK & $\begin{array}{l}\text { Prospective } \\
\text { cohort }\end{array}$ & 1547 & $73.6 \pm 4.5$ & 1.53 & $1.06-2.21$ & $25-50$ & $\begin{array}{l}\text { Age, season of vitamin D collection, } \\
\text { education, sex, BMl, smoking, alcohol } \\
\text { consumption, and depressive symptoms }\end{array}$ \\
\hline Buell [12] & 2010 & USA & Cross-sectional & 318 & $73.5 \pm 8.1$ & 2.21 & $1.13-4.32$ & $\leq 50$ & $\begin{array}{l}\text { Age, race, sex, body mass index, and } \\
\text { education, kidney function, multivitamin } \\
\text { use, season, diabetes, hypertension, plasma } \\
\text { homocysteine, and ApoE allele status }\end{array}$ \\
\hline Annweiler [13] & 2011 & France & Cross-sectional & 288 & $86.0 \pm 0.4$ & 2.57 & $1.05-6.27$ & $<25$ & $\begin{array}{l}\text { Fully adjusted but without detailed } \\
\text { information }\end{array}$ \\
\hline Nagel [14] & 2015 & Germany & Cross-sectional & 1373 & $75.6 \pm 6.57$ & 1.08 & $0.60-1.92$ & $\leq 50$ & $\begin{array}{l}\text { Adjusted for age, sex, school education, } \\
\text { smoking status, season, alcohol } \\
\text { consumption, BMl, and history of } \\
\text { depression }\end{array}$ \\
\hline
\end{tabular}

dementia in comparison with those with serum 25(OH)D level $>50 \mathrm{nmol} / \mathrm{L}$. Findings of this meta-analysis are indirectly supported by a recent study covering 5010 subjects free of dementia at baseline indicating that higher vitamin $\mathrm{D}$ concentration is associated with lower dementia risk after a 17-year follow up [20].

Attempts have been made to explore the effects of vitamin $\mathrm{D}$ supplementation in preventing $\mathrm{AD}$ or dementia in recent years, while the results are inconsistent [24-26]. In a prospectively followed cohort study of 498 older women aged 75 years and older, it was found that higher vitamin D dietary intake can lower the risk of developing AD after a 7 years follow-up [24]. In comparison, in a randomized double-blind placebo-controlled trial recruiting 4143 women aged 65 and older without probable dementia at baseline, no association between vitamin $\mathrm{D}$ combined with calcium carbonate treatment supplement and incident cognitive impairment was observed [26]. Thus, further studies recruiting a large number of participants by considering the gender and ethnic differences and with

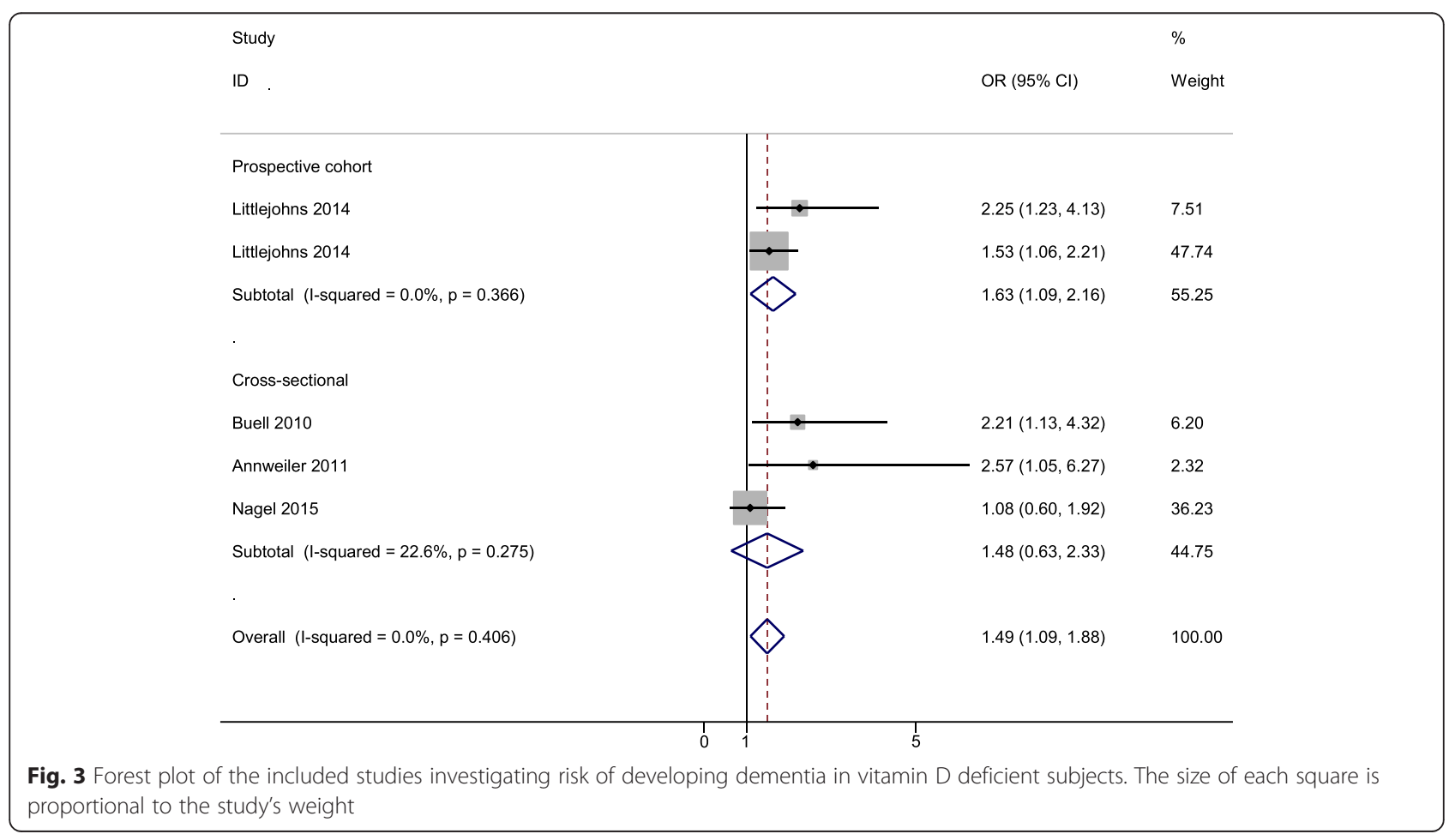


different vitamin D dosages are encouraged to evaluate the efficacy of vitamin D supplementations in preventing $\mathrm{AD}$ and dementia.

Some limitations in the present meta-analysis need to be considered. First, the number of eligible studies is relatively small. Second, men and women have different $\mathrm{AD}$ incidence overall [27, 28], while there are not enough data to perform gender subgroup analysis to explore the effect of gender on the association between vitamin $\mathrm{D}$ deficiency and risk of developing $\mathrm{AD}$. Third, the available data cannot permit us to exclude the possibility that the associations between vitamin $\mathrm{D}$ and $\mathrm{AD}$ or dementia are a result of disease development rather than being causal.

\section{Conclusions}

In summary, available data shows that vitamin D deficiency may be associated with increased risk of developing $\mathrm{AD}$ and dementia. There is a strong need to further confirm the associations by more prospective cohort studies. In addition, in view of the safe and cost-effective interventions to improve vitamin D status, the potential beneficial effects of vitamin $\mathrm{D}$ supplementation in preventing $A D$ and dementia should be paid attention to and assessed by the neurologists and geriatricians.

\section{Competing interests}

The authors declare that they have no competing interests.

\section{Authors' contributions}

HFJ conceived and designed the experiments; LS and HFJ collected the data, performed the analysis. LS and HFJ analyzed the results. LS and HFJ wrote the paper. Both authors read and approved the final manuscript.

\section{Acknowledgments}

This work was supported by the National Natural Science Foundation of China (Grant No. 31370745) and the Shandong Provincial Natural Science Foundation (Grant No. ZR2014CL008).

Received: 26 May 2015 Accepted: 27 July 2015

Published online: 01 August 2015

\section{References}

1. Alzheimer's Association. 2014 Alzheimer's disease facts and figures. Alzheimers Dement. 2014;10:e47-92.

2. Brookmeyer R, Johnson E, Ziegler-Graham K, Arrighi HM. Forecasting the global burden of Alzheimer's disease. Alzheimers Dement. 2007:3:186-91.

3. Gezen-Ak D, Yılmazer S, Dursun E. Why vitamin D in Alzheimer's disease? The hypothesis. J Alzheimers Dis. 2014:40:257-69.

4. Morley JE. Dementia: does vitamin D modulate cognition? Nat Rev Neurol. 2014;10:613-4.

5. Pogge E. Vitamin D, and Alzheimer's disease: is there a link? Consult Pharm. 2010:25:440-50.

6. Evatt ML, DeLong MR, Khazai N, Rosen A, Triche S, Tangpricha V. Prevalence of vitamin D insufficiency in patients with Parkinson disease and Alzheimer disease. Arch Neurol. 2008;65:1348-52.

7. Sato Y, Asoh T, Oizumi K. High prevalence of vitamin D deficiency and reduced bone mass in elderly women with Alzheimer's disease. Bone. 1998:23:555-7.

8. Zhao Y, Sun Y, Ji HF, Shen L. Vitamin D levels in Alzheimer's and Parkinson's diseases: a meta-analysis. Nutrition. 2013:29:828-32

9. Littlejohns TJ, Henley WE, Lang IA, Annweiler C, Beauchet O, Chaves PH, et al. Vitamin $D$ and the risk of dementia and Alzheimer disease. Neurology. 2014;83:920-8.
10. Afzal S, Bojesen SE, Nordestgaard BG. Reduced 25-hydroxyvitamin D and risk of Alzheimer's disease and vascular dementia. Alzheimers Dement. 2014;10:296-302.

11. Holick MF. Vitamin D deficiency. N Engl J Med. 2007:357:266-81.

12. Buell JS, Dawson-Hughes B, Scott TM, Weiner DE, Dallal GE, Qui WQ, et al. 25-Hydroxyvitamin D, dementia, and cerebrovascular pathology in elders receiving home services. Neurology. 2010;74:18-26.

13. Annweiler C, Fantino B, Le Gall D, Schott AM, Berrut G, Beauchet O. Severe vitamin $D$ deficiency is associated with advanced-stage dementia in geriatric inpatients. J Am Geriatr Soc. 2011;59:169-71.

14. Nagel G, Herbolsheimer F, Riepe M, Nikolaus T, Denkinger MD, Peter R, et al. Serum Vitamin D concentrations and cognitive function in a populationbased study among older adults in South Germany. J Alzheimers Dis. 2015;45:1119-26.

15. Zittermann A. Vitamin D, and cardiovascular disease. Anticancer Res. 2014;34:4641-8.

16. Muscogiuri G, Mitri J, Mathieu C, Badenhoop K, Tamer G, Orio F, et al. Mechanisms in endocrinology: vitamin D as a potential contributor in endocrine health and disease. Eur J Endocrinol. 2014;171:R101-10.

17. Holick MF. Vitamin D: importance in the prevention of cancers, type 1 diabetes, heart disease, and osteoporosis. Am J Clin Nutr. 2004;79:362-71.

18. Dickens AP, Lang IA, Langa KM, Kos K, Llewellyn DJ. Vitamin D, cognitive dysfunction and dementia in older adults. CNS Drugs. 2011;25:629-39.

19. Schlögl M, Holick MF. Vitamin D and neurocognitive function. Clin Interv Aging. 2014;9:559-68.

20. Knekt $P$, Sääksjärvi $K$, Järvinen $R$, Marniemi J, Mönnistö S, Kanerva N, et al. Serum 25-hydroxyvitamin d concentration and risk of dementia. Epidemiology. 2014;25:799-804

21. Annweiler C, Schott AM, Berrut G, Chauvire V, Le Gall D, Inzitari M, et al. Vitamin D and ageing: neurological issues. Neuropsychobiology. 2010;62:139-50.

22. Etgen T, Sander D, Bickel H, Sander K, Förstl H. Vitamin D deficiency, cognitive impairment and dementia: a systematic review and meta-analysis. Dement Geriatr Cogn Disord. 2012;33:297-305.

23. Balion C, Griffith LE, Strifler L, Henderson M, Patterson C, Heckman G, et al. Vitamin D, cognition, and dementia: a systematic review and meta-analysis. Neurology. 2012;79:1397-405.

24. Annweiler C, Rolland Y, Schott AM, Blain H, Vellas B, Herrmann FR, et al. Higher vitamin D dietary intake is associated with lower risk of alzheimer's disease: a 7-year follow-up. J Gerontol A Biol Sci Med Sci. 2012;67:1205-11.

25. Taghizadeh M, Talaei SA, Djazayeri A, Salami M. Vitamin D supplementation restores suppressed synaptic plasticity in Alzheimer's disease. Nutr Neurosci. 2014;17:172-7.

26. Rossom RC, Espeland MA, Manson JE, Dysken MW, Johnson KC, Lane DS, et al. Calcium and vitamin D supplementation and cognitive impairment in the women's health initiative. J Am Geriatr Soc. 2012;60:2197-205.

27. Seshadri S, Wolf PA, Beiser A, Au R, McNulty K, White $R$, et al. Lifetime risk of dementia and Alzheimer's disease: the impact of mortality on risk estimates in the Framingham study. Neurology. 1997:49:1498-504.

28. Miech RA, Breitner JC, Zandi PP, Khachaturian AS, Anthony JC, Mayer L. Incidence of AD may decline in the early 90 s for men, later for women: the Cache County study. Neurology. 2002;58:209-18.

\section{Submit your next manuscript to BioMed Central and take full advantage of:}

- Convenient online submission

- Thorough peer review

- No space constraints or color figure charges

- Immediate publication on acceptance

- Inclusion in PubMed, CAS, Scopus and Google Scholar

- Research which is freely available for redistribution 